\title{
Insular Tumours
}

\author{
Francesco Signorelli1, Giuseppe Barbagallo², Rodolfo Maduri ${ }^{1}$, \\ Claudio Schonauer ${ }^{3}$, Jacques Guyotat ${ }^{4}$ and Kost Elisevich ${ }^{5}$ \\ ${ }^{1}$ Dept. of Neurosurgery, University "Magna Græcia", Catanzaro \\ ${ }^{2}$ Dept. of Neurosurgery, University of Catania \\ ${ }^{3}$ Dept. of Neurosurgery, La Schiana Hospital, Napoli \\ ${ }^{4}$ Dept. of Neurosurgery, Hôpital Neurologique et Neurochirurgical "P. Wertheimer", Lyon \\ ${ }^{5}$ Dept. Of Neurosurgery, Henry Ford Hospital, Detroit, \\ 1,2,3Italy \\ ${ }^{4}$ France \\ ${ }^{5}$ United States of America
}

\section{Introduction}

Tumours affecting the insular structure and perisylvian opercula are frequently managed conservatively regardless of their nature and clinical evolution, even if impending infiltration of nearby eloquent areas will further promote dysfunction. Our experience and those of others [Duffau et al., 2005; Hentschel \& Lang, 2005; Sanai et al., 2010; Lang et al., 2001; Signorelli et al., 2010] has demonstrated that wide surgical resection of these lesions is nonetheless feasible since tumour burden often displaces more than it incorporates eloquent sites [Duffau et al., 2009; Hentschel \& Lang, 2005; Sanai et al., 2010; Signorelli et al., 2010] and other sites will often compensate for the lost function of infiltrated tissues. However, accurate anatomic and functional knowledge of the sylvian fissure and structures located nearby is essential to perform any surgical act in this area, in order to decrease the risk of postoperative permanent deficits. The aim of our chapter is to provide the reader with an updated review of insular anatomy and function, of clinical presentation and diagnosis of insular gliomas and point out technical details helpful in guiding surgery through this region.

\section{Surgical anatomy and functions of the insula}

The insula of Reil, composed of anterior and posterior lobules divided by a central sulcus, is an anatomically and functionally complex structure, situated at the bottom of the sylvian fissure and involved in complex anatomicofunctional relations. It is pyramid-shaped and its perimeter is defined by anterior, superior and inferior periinsular sulci. The limen insulae represents its medial threshold. It is a white matter structure extending from the anterior perforated substance to the insular pole along the sylvian stem and situated in parallel with the lateral olfactory stria [Türe et al., 1999]. Deep to the central portion of the insula, in a lateral-to-medial direction, lie the extreme capsule, claustrum, external capsule and putamen with its subjacent globus pallidus. Superiorly, at the level of the periinsular sulcus, 
is the corticospinal tract; anteroinferiorly, the uncinate fasciculus; and, posteriorly, along the same sulcus, the arcuate fasciculus. The blood supply of the insula is derived from the second (M2) segment of the middle cerebral artery (MCA) through its short and mediumsized perforating vessels. Long perforators overlying the posterior lobule are larger in diameter and may supply the corona radiata, particularly, the corticospinal and thalamocortical fibers [Hentschel \& Lang, 2005]. Most of the lenticulostriate branches originate around the MCA bifurcation and arise in a nearly even distribution from before and after the bifurcation although the number arising from M1 increases commensurate with its length [Tanriover et al., 2004]. The mean distance from the insular apex to the lateralmost lenticulostriate artery, the length of M1 notwithstanding, is less than $1.5 \mathrm{~cm}$ [Tanriover et al., 2004]. The periinsular sulcus marks the transition from M2 to M3 whereas the convexity surface of the opercula demarcates the M4 segment of the MCA. As a paralimbic structure, the insula is located at the crossroad of allo- and neocortex. It is adjacent to perisylvian essential language areas, the primary auditory area, both the primary motor (PMA) and sensory (PSA) areas of the lower face in addition to their associated subcortical pathways. The insula subserves several functions including olfaction, taste, reciprocal visual-vestibular inhibition and the integration of sensory input with autonomic and emotional responses. It is, in fact, considered an accessory sensorimotor area, involved in motor planning and the planning and initiation of speech articulation [Naidich et al., 2004]. Sympathetic control of cardiovascular tone and pain perception suggest a further integrative role for the insula in association with proximate limbic structures. In fact, the insula is thought to be critically involved in the biobehavioural dysfunction characteristic of schizophrenia [Makris et al., 2006] and sleep regulation [Murphy et al., 2009].

\section{Clinical presentation and diagnosis of insular gliomas}

The clinical presentation of gliomas is somewhat associated with grade. Insular low grade gliomas (LGGs) present with epilepsy in $58 \%$ of cases with little or no neurological impairment [Duffau et al., 2005]. On the other hand, high grade gliomas (HGGs) frequently cause surrounding vasogenic edema with tissue infiltration, resulting in local and hemispheric mass effect and sensorimotor and/or language deficits. Moreover, neuropsychological assessment often reveals a cognitive decline, most likely ensuing from regional edema, seizures or the adverse effects of antiepileptic drugs (AEDs) [Klein et al., 2003; Meyers \& Hess, 2002]. The semiology of insular epilepsy reflects the heterogeneity of the region's functional anatomy [Ryvlin et al., 2006]. It may mimic temporal lobe epilepsy [Barba et al., 2007; Isnard et al., 2004; Penfield \& Faulk, 1955] or nocturnal hypermotor epilepsy of frontal lobe origin [Dobesberger et al., 2008; Ryvlin et al., 2006]. Other common ictal features are those of a simple partial epilepsy with respiratory, viscerosensitive or oroalimentary symptoms [Guénot \& Isnard, 2008; Ostrowsky et al., 2000;]. Spread to the suprasylvian opercular cortex may produce facial paresthesia or laryngeal constriction, gustatory illusions and hypersalivation with postictal facial paresis [Isnard et al., 2004; Prats et al., 1999]. Infrasylvian opercular ictal spread, on the other hand, may produce auditory hallucinations or a sensory aphasia [Bancaud, 1987]. Further spread of activity over the central convexity gives rise to contralateral hemisensory or hemimotor manifestations.

Magnetic resonance imaging (MRI) with T2-weighted and Fluid-Attenuated Inversion Recovery (FLAIR) images best delineates the extent of tumour infiltration, which can be limited to the insular lobe (Yasargil type 3a) or reach the perisylvian opercula (type 3b) and 
other paralimbic areas, namely the orbitofrontal and temporopolar regions (type 5), with or without involvement of core limbic structures [Yasargil et al., 1992] (fig. 1). Functional MRI [Roux et al., 2008; Signorelli et al., 2003;), magnetoencephalography [Mäkelä et al., 2006] and positron emission tomography [Sobottka et al., 2002] help define the neighbouring cortical distribution of language, auditory, sensory and motor function. Moreover, diffusion tensor imaging (DTI) and, in particular, tractography helps delineate the major interconnecting tracts surrounding the insula [Makris et al., 2006]. Merging 3-D cortical and subcortical anatomical pictures with individual functional maps provides highly relevant information for surgical planning. Ultimately, such information is supplemented by intraoperative cortical and subcortical stimulation as the final measure to optimize tumour removal while preserving local function [Duffau et al., 2006; Signorelli et al., 2010].

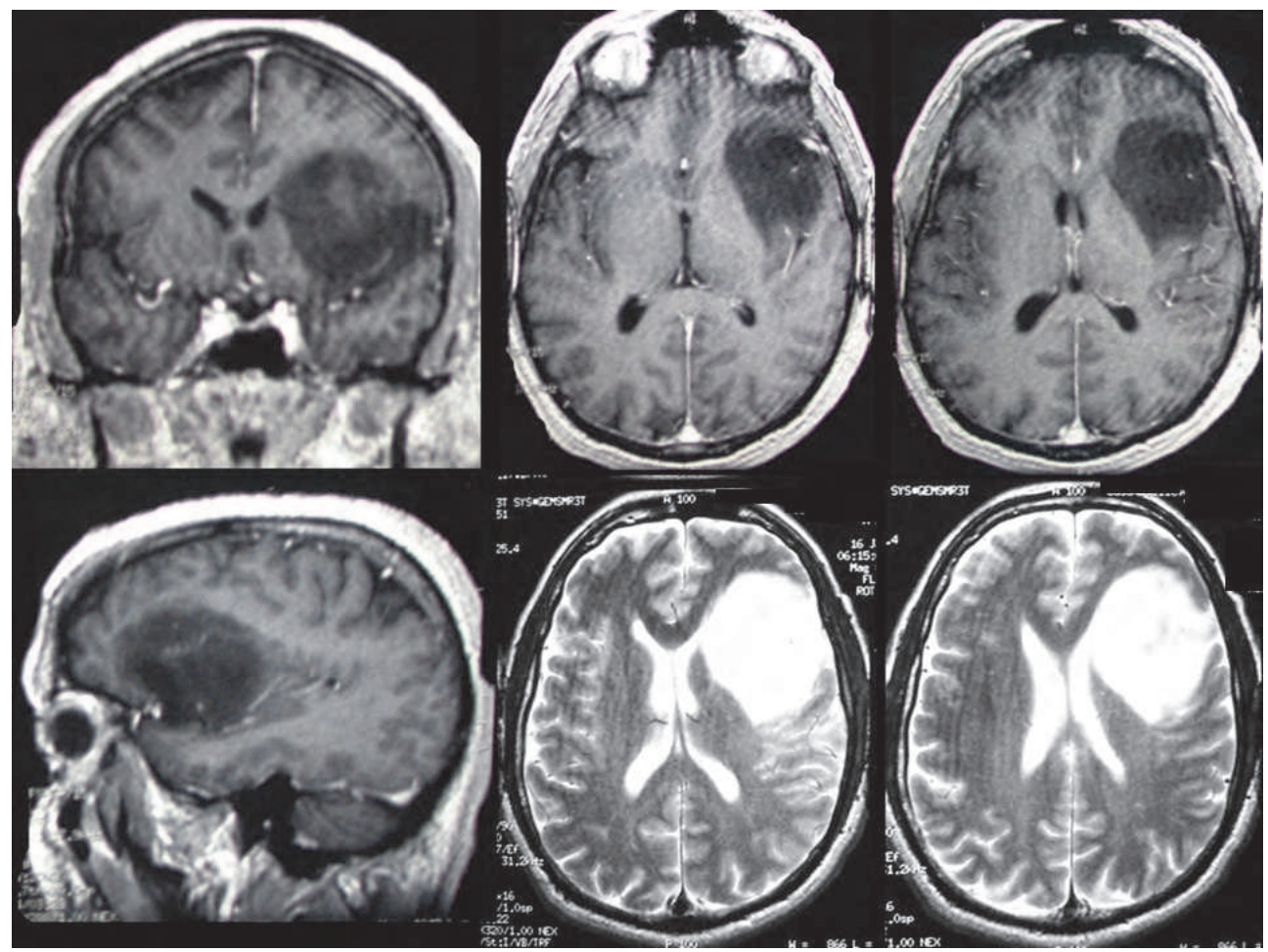

Fig. 1. Preoperative gadolinium enhanced T1- and T2-weighted MRI of a LGG infiltrating, left insular region, frontal and temporal operculum and fronto-orbital and temporopolar areas (5A of Yasargil classification). The tumour extends above the superior insular sulcus into the corona radiata.

\section{Surgical procedure}

Patients are positioned with a rest pad under the ipsilateral shoulder with the head turned $60^{\circ}$ contralaterally, in order to allow the frontal and temporal lobes to separate when released so as to expose the sylvian fissure and avoid retraction. Moreover, this 
positioning provides a better orientation for the surgical perspective toward the posterior insular lobule, which is hidden by both the pre- and postcentral gyri [Hentschel \& Lang, 2005]. We routinely apply cortico-subcortical electrical stimulation mapping (ESM) in order to locate and preserve eloquent sites and perform a tumour resection the limits of which are both anatomical and functional. An asleep-awake-asleep technique is used when operating on the dominant hemisphere. Neuronavigation is also useful for defining tumour boundaries and anatomic relationships with neural and vascular structures. The craniotomy is planned to include the whole perisylvian area from the pars orbitalis of the third frontal gyrus to the postcentral sulcus, the widest sulcus opening into the sylvian fissure and which, in general, delimits the posterosuperior corner of the insula (fig. 2).

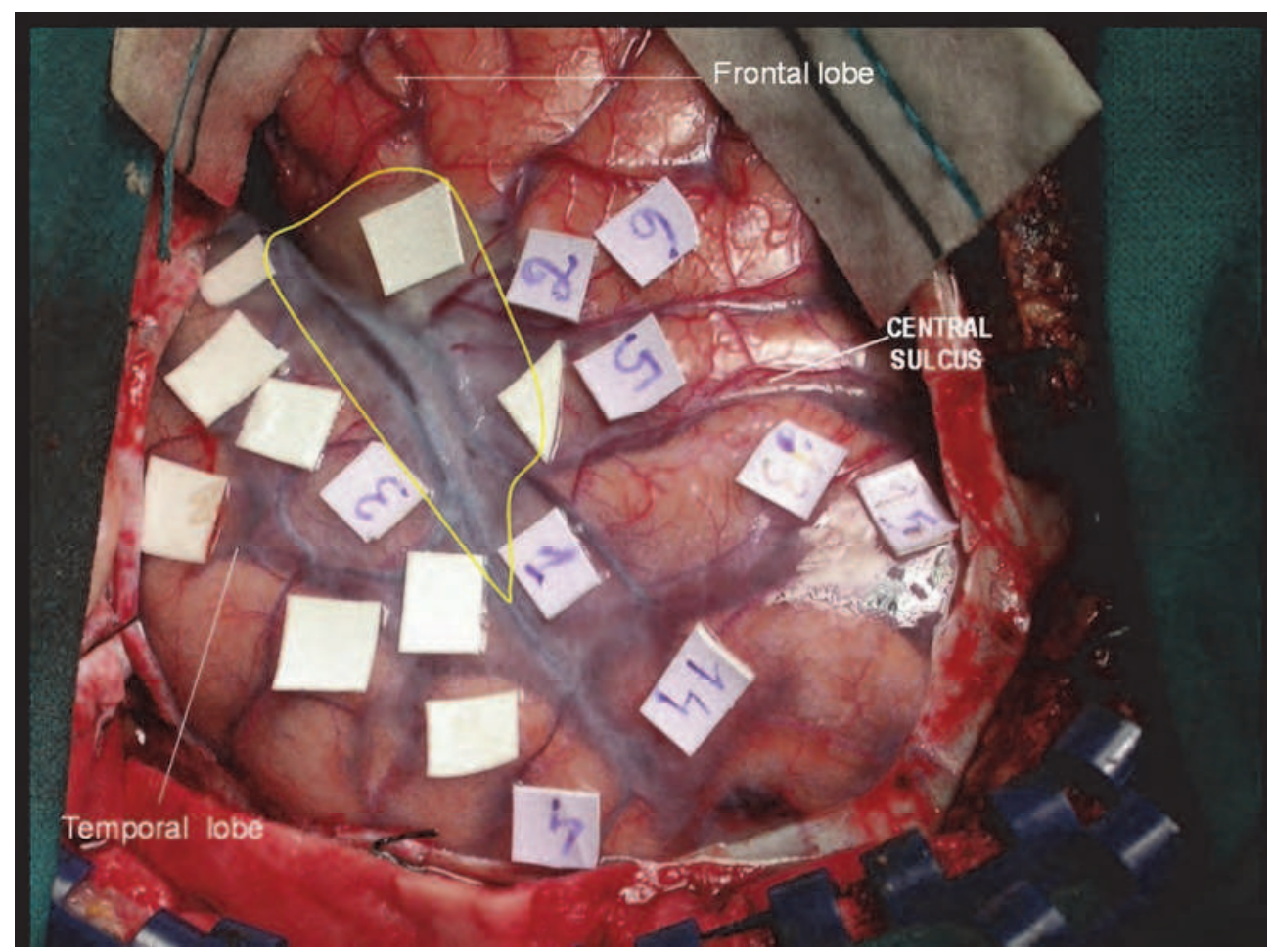

Fig. 2. Patient depicted in fig. 1. Craniotomy exposing widely the sylvian fissure, from pars orbitalis of F3 to the postcentral sulcus. Numbered tags indicate language sites $(6,2$ speech arrest; 1, 3, 4 paraphasias; 13, 14, 15 anomia) and the primary motor area of the face (5).It is noteworthy that the functional sites are displaced at the periphery of the opercular tumoural infiltration (outlined in yellow).

Following ESM aimed at confirming the location of cortical language and sensorimotor areas, the superficial part of the lesion, which often infiltrates one or more of the frontal, parietal and temporal opercula, is removed so as to gain safe access into the depth of the sylvian fissure (fig. 3). 


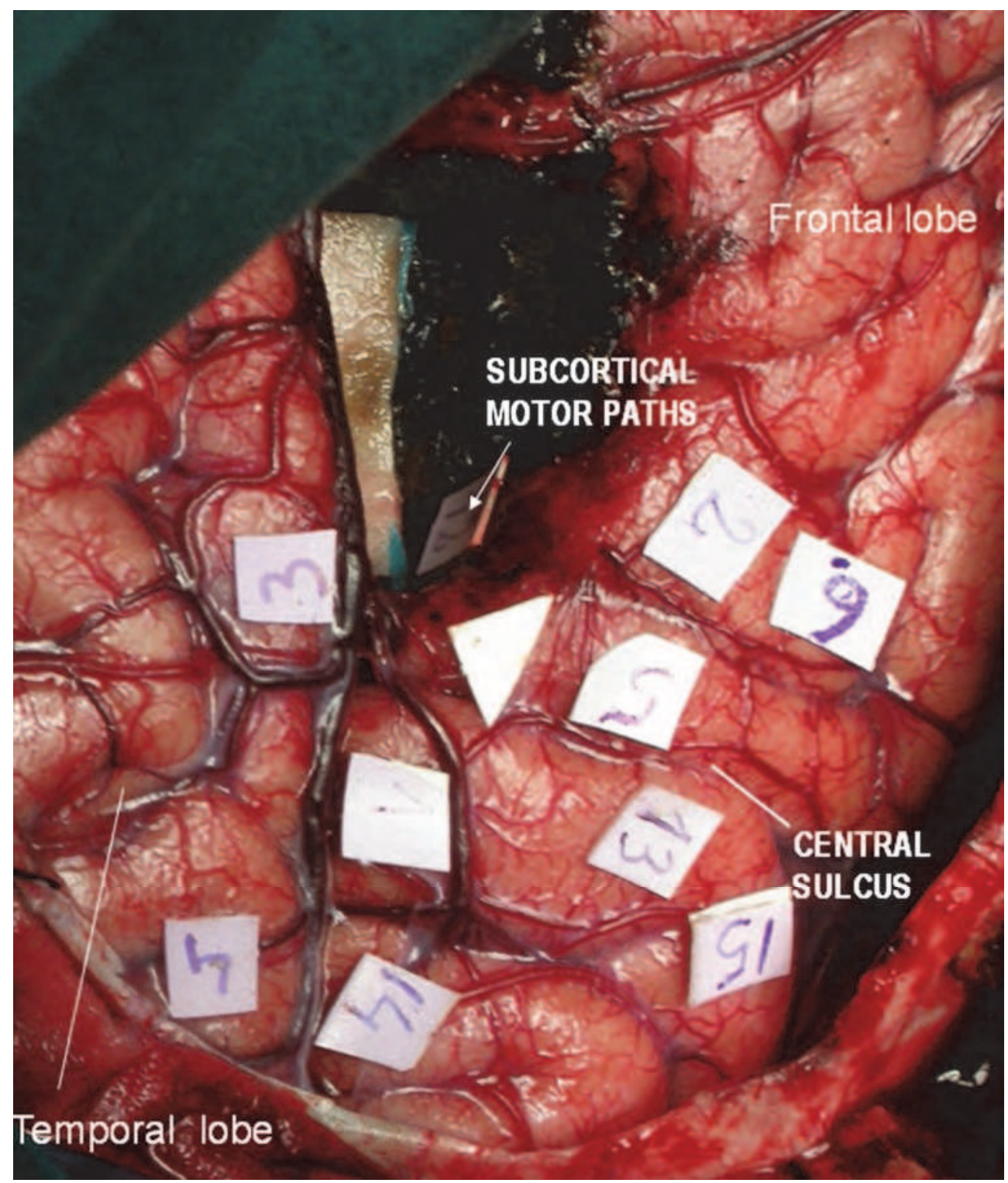

Fig. 3. After opercular resection, it is possible to reach the insular surface without retraction. Subcortical stimulation located motor pathwaysin the corona radiata, defining the posterior limit of tumoural resection in depth.

In most cases, the tumour displaces M2 branches centrifugally, indicating to the surgeon the site on the insular surface where the tumor is most proximate. Further use of ESM is required to search for possible language representation over the dominant insular cortex (fig. 4). The removal of insular gyri, when not harbouring language areas, is conducted 
medially to the putamen which is generally visible under the microscope as a gray, compact tissue that underlies a thin barrier of white matter [Yasargil et al., 1992]. Subcortical stimulation is used repeatedly beginning at a distance of two $\mathrm{cm}$ lateral to the posterior limb of the internal capsule, as measured by neuronavigational methods, in order to identify and preserve subcortical motor pathways. It is especially useful when extending tumour resection above the superior insular sulcus, where pyramidal fibers coursing through the corona radiata are found to be more superficial and where anatomic landmarks are lacking. Resection below the lenticular nucleus, at the level of the inferior limiting sulcus, may likewise interfere with sublenticular fibers of the posterior limb of the internal capsule. These are arranged in an anteroposterior direction to include the auditory and optic radiations [Rhoton, 2007]. Of utmost importance is the recognition of the vascular anatomy. Avulsion of the short branches of the MCA may injure the parent vessel with serious consequences. The long perforators, supplying the corona radiata, must be respected also to avoid ischemic injury of the white matter (Lang et al., 2001). In the area of the limen insulae, the lenticulostriate arteries originate commonly from the medial or superior aspect of the MCA, five mm or less around its bifurcation Their injury could lead to ischemic damage of the internal capsule. Electrical stimulation of the short and long gyri may result in speech arrest, particularly, in cases where a LGG has infiltrated the classic language area in the perisylvian opercula (fig. 4).

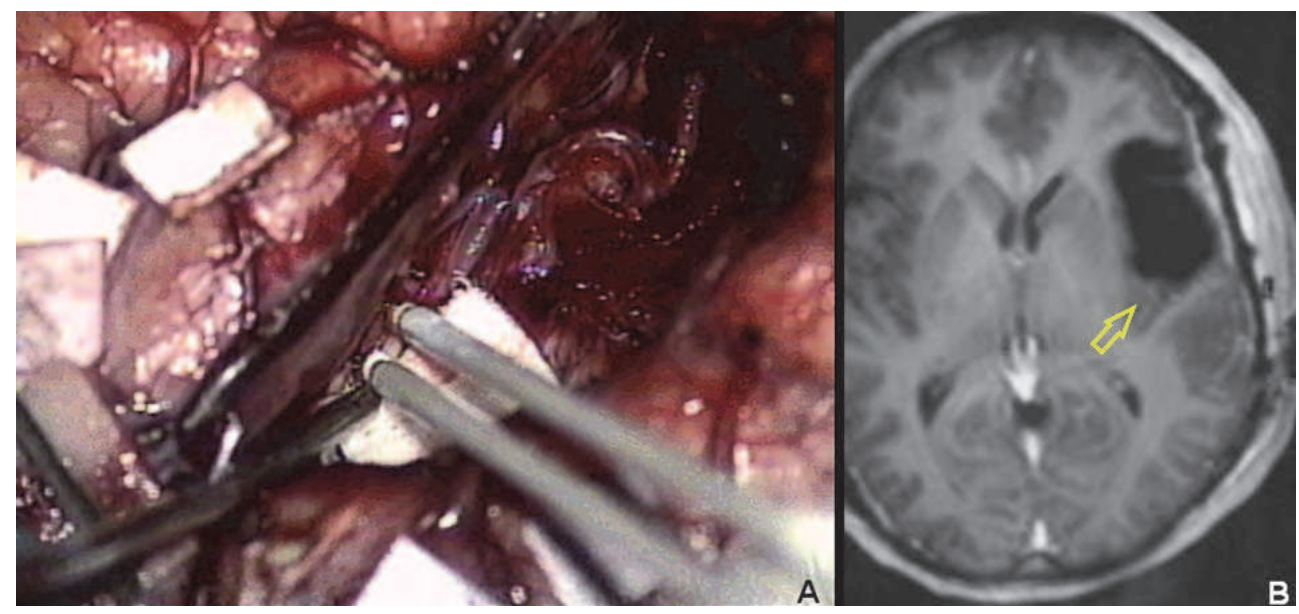

Fig. 4. A) The bipolar probe stimulates the cortical surface of posterior insular lobe. In this patient, patient, depicted in previous figures, insular cortical stimulation elicited speech arrest, which put a halt to tumoural resection. B) A postoperative (one month) T1-weighted Gd-enhanced MRI the tumoural residue is clearly seen at the level of the posterior insular lobe, where ESM elicited speech arrest (yellow arrow).

Seizures induced by ESM may be aborted by cooling the cortical surface with ice cold saline. The insular cortical areas where stimulation may evoke abdominal sensations or phenomena such as nausea, borborygmi, belching or chewing and/or tongue movements without speech arrest are not considered eloquent sites and may be removed when infiltrated by tumour. Stimulation of the uncinate fasciculus during removal of an infiltrated limen 
insulae is typically uneventful. On the other hand, stimulation of the white matter at the anterolateral border of the frontal horn of the left lateral ventricle will trigger speech arrest by depolarization of the subcallosal fasciculus and put a halt to resection (fig. 5). The posterosuperior limit of tumour resection is typically defined by identifying motor fibers in the corona radiata using ESM applied above the insular superior limiting sulcus (fig. 5). Most patients show immediate postoperative neurological aggravation which generally lasts no longer than one to two months emphasizing the proximity of eloquent structures.

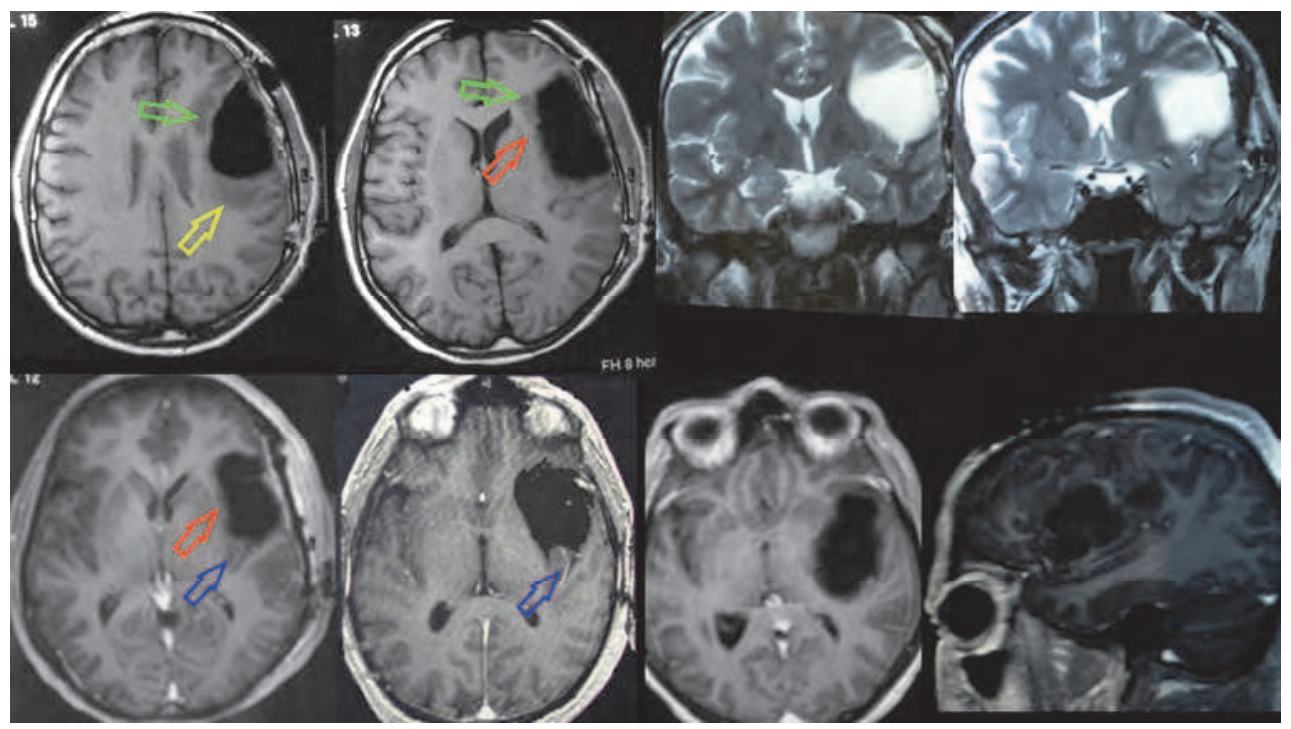

Fig. 5. One month Postoperative (one month) T1-weighted Gd-enhanced and T2-weighted MRI of the same patient previously illustrated, showing a subtotal tumour removal. Tumour remains at the level of the subcallosal fasciculus (green arrow), where stimulation elicited speech arrest with preserved repetition, at the level of the inferior occipitofrontal fasciculus (IOF, red arrow) in the anterior portion of capsula extrema, where stimulation elicited semantic paraphasias, into the corona radiata where subcortical motor pathways run (yellow arrow) and at the posterior insular lobe, where stimulation triggered speech arrest and dysarthria (blue arrow).

\section{Discussion}

Several well-designed controlled studies indicate that the degree of surgical resection of brain gliomas affects survival and the quality of life of patients [Pignatti et al., 2002; Stupp et al., 2005]. Significant cytoreduction is effective not just in reducing the mass effect of the lesion but it is more likely to remove the contingent of neoplastic cells that may manifest more aggressive behaviour through proliferation and invasiveness [Sanai et al., 2010]. Aggressive tumour removal is also more likely to mitigate a lesion-associated epilepsy [Sanai et al., 2010]. A significant percentage of LGGs, up to $25 \%$ in one series [Duffau \& Capelle, 2004], invade the insula, raising doubt regarding their resectability. Surgical pursuit of such tumours is recommended to forestall clinical impairment, improve survival and 
lengthen the recurrence-free period [Duffau et al., 2009; Sanai et al., 2010]. Since the first report by Yasargil (Yasargil et al., 1992), few authors have dealt with the surgical treatment of tumours infiltrating the insula [Duffau et al., 2005; Hentschel \& Lang, 2005; Lang et al., 2001; Sanai et al., 2010; Zentner et al., 1996]. A number of authors have emphasized the importance of functional mapping because of the eloquent nature of both insular and periinsular structures [Signorelli et al., 2003; Sobottka et al., 2002]. The use of sensory and/or motor evoked potentials [Zentner et al., 1996] or ESM [Duffau et al., 2005, 2006, 2009; Sanai et al., 2010; Signorelli et al., 2010] provide additional intraoperative landmarks by which to safely resect insular masses. Dominant hemisphere cortical language localization is advisable although language interference from direct stimulation of the insular cortex has seldom been reported [Duffau et al., 2005; Hentschel \& Lang, 2005]. In our experience, insular tumours infiltrating the opercular region of the dominant hemisphere are responsible for functional reshaping of language areas with relocation onto the insular cortex. The insula is a secondary functional area that has the potential to take charge of lost function brought about by tumour infiltration of primary eloquent sites. Patients may present without a phasic deficit in language in such circumstances. Thus, testing language function in such patients harboring a dominant-sided insular LGG may reduce the risk of postoperative permanent impairment, which comes about in $14 \%$ of subjects when no language mapping is performed [Zentner et al., 1996].

\section{Conclusion}

Insular gliomas represent a surgical challenge because of the diverse functional importance of the insula and surrounding brain. Its accessibility within the convoluted perisylvian structure adds to this challenge. Newly acquired knowledge of structural and dynamic functional organization of the insula provide the surgeon the opportunity to plan and execute effective surgical resection of gliomas, once deemed inoperable, with acceptable risk. It follows that optimization of tumour removal coupled with an ultimate return of function improves the quality of life and survival.

\section{References}

Bancaud, J. (n.d.). Clinical symptomatology of epileptic seizures of temporal origin. Revue neurologique, Vol.43, No.5, (n.d. 1987), pp.392-400, ISSN 0035-3787

Barba, C.; Barbati, G.; Minotti, L.; Hoffman, D. \& Kahane, P. (2006). Ictal clinical and scalpEEG findings differentiating temporal lobe epilepsies from temporal 'plus' epilepsies. Brain, Vol.130, No.7, (May 2007), pp.1957-1967, ISSN 1460-2156

Dobesberger, J.; Ortler, M.; Unterberger, I.; Walser, G.; Falkenstetter, T.; Bodner, T.; Benke, T.; Bale, R.; Fiegele, T.; Donnemiller, E.; Gotwald, T. \& Trinka E. (2007). Successful surgical treatment ofinsular epilepsy with nocturnal hypermotor seizures. Epilepsia, Vol.49, No.1, (October 2008), pp.159-162, ISSN 1528-1167

Duffau, H. \& Capelle, L. (2004). Preferential brain locations of low-grade gliomas. Cancer, Vol.100, No.12, (April 2004), pp.2622-2626, ISSN 1097-0142

Duffau, H.; Taillandier, L.; Gatignol, P. \& Capelle, L. (2005). The insular lobe and brain plasticity: Lessons from tumor surgery. Clinical Neurology and Neurosurgery, Vol.108, No.6, (September 2005), pp.543-548, ISSN 0303-8467 
Duffau, H,; Moritz-Gasser, S. \& Gatignol, P. (2009). Functional outcome after language mapping for insular for World Health Organization Grade II gliomas in the dominant hemisphere with 24 patients. Neurosurgical Focus, Vol.27, No.2, (August 2009), pp. 1-10, ISSN 1092-0684

Guénot, M. \& Isnard, J. (2008). Epilepsy and insula. Neurochirurgie, Vol.54, No.3, (May 2008), pp.374-381, ISSN 0028-3770

Hentschel, SJ. \& Lang, FF. (2005). Surgical resection of intrinsic insular tumors. Neurosurgery, Vol.57, No.1, (July 2005), pp.176-183, ISSN 1524-4040

Isnard, J.; Guénot, M.; Sindou, M. \& Mauguière, F. (2004). Clinical manifestations of insular lobe seizures: a stereo-electroencephalographic study. Epilepsia, Vol.45, No.9, (April 2004), pp.1079-1090, ISSN 1528-1167

Klein, M.; Engelberts, NH.; van der Ploeg, HM.; Kasteleijn-Nolst Trenité, DG.; Aaronson, NK.; Taphoorn, MJ.; Baaijen, H.; Vandertop, WP.; Muller, M.; Postma, TJ. \& Heimans, JJ. (n.d.). Epilepsy in low-grade gliomas: the impact on cognitive function and quality of life. Annals of Neurology, Vol.54, No.4, (September 2003), pp.514-520, ISSN 0364-5134

Lang, FF.; Olansen, NE.; DeMonte, F.; Gokaslan, ZL; Holland, EC.; Kalhorn, C. \& Sawaya R. (2000). Surgical resection of intrinsic insular tumors: Complication avoidance. Journal of Neurosurgery, Vol.95, No.4, (October 2001), pp.638-650, ISSN 0022-3085

Mäkelä, JP.; Forss, N.; Jääskeläinen, J.; Kirveskari, E.; Korvenoja, A. \& Paetau, R. (2005). Magnetoencefalography in neurosurgery. Neurosurgery, Vol.59, No.3, (June 2006), pp.493-510, ISSN 0022-3085

Makris, N.; Goldstein, J.; Kennedy, D.; Hodge, S.; Caviness, V.; Faraone, S.; Tsuang, M.\& Seidman, L. (2005). Decreased volume of left and total anterior insular lobule in schizophrenia. Schizophrenia Research, Vol.83, No.2, (June 2006), pp.155-171, ISSN 0920-9964

Meyers, C. \& Hess, KR. (2003). Multifaceted endpoints in brain tumor clinical trials: cognitive deterioration precedes MRI progression. (2002). Neuro-oncology, Vol.5, No.2, (December 2002), pp.89-95, ISSN 1523-5866

Murphy, M.; Riedner, BA.; Huber, R.; Massimini, M.; Ferrarelli, F; \& Tononi, G. Source modelling sleep slow waves. (2008). Proceedings of the national academy of sciences of the United States of America, Vol.106, No.5, pp.1608-1613, ISSN 0027-8424

Naidich, TP.; Kang, E.; Fatterpekar, GM.; Delman, BN.; Gultekin, SH.; Wolfe, D.; Ortiz, O.; Yousry, I.; Weisman, M. \& Yousry, TA. (2003). The insula: anatomic study and MR imaging display at 1.5T. American Journal of Neuroradiology, Vol.25, No.2, (February 2004), pp.222-232, ISSN 0195-6108

Ostrowsky, K.; Isnard, J.; Ryvlin, P.; Guénot, M.; Fischer, C. \& Mauguière, F. (2000). Functional mapping of the insular cortex: clinical implication in temporal lobe epilepsy. Epilepsia, Vol.41, No.6, (June 2000), pp.681-686, ISSN 0013-9580

Penfield, W. \& Faulk, ME Jr. (1955). The insula: further observations on its function. Brain, Vol.78, No.4 , (n.d.), pp.445-470, ISSN 0006-8950

Pignatti, F.; van den Bent, M.; Curran, D.; Debruyne, C.; Sylvester, R.; Therasse, P.; Afra, D.; Cornu, P.; Bolla, M.; Vecht, C. \& Karim, AB. (2001). Prognostic factors for survival in adult patients with cerebral low-grade glioma. Journal of Clinical Oncology, Vol.20, No.8, (April 2002), pp.2076-2084, ISSN 1527-7755 
Prats, JM.; Garaizar, C.; Garcia-Nieto ML \& Madoz, P. (1999). Opercular epileptic syndrome: an unusual form of benign partial epilepsy in childhood. Revista de Neurología, Vol.29, No.4, (August 1999), p. 375-380. ISSN: 0210-0010

Rhoton, A.L. Jr. The cerebrum. Anatomy. (2002). Neurosurgery, Vol.61, No.1, (July 2007), pp.37-118, ISSN 0022-3085

Roux, FE.; Boukhatem, L.; Draper, L.; Sacko, O. \& Démonet, J.F. (2008). Cortical calculation localization using electrostimulation. Journal of neurosurgery, (December 2008), Vol.110, No.6, pp.1291-1299, ISSN 0022-3085

Ryvlin, P.; Minotti, L.; Demarquay, G.; Hirsch, E.; Arzimanoglou, A.; Hoffman, D.; Guénot, M.; Picard, F.; Rheims, S. \& Kahane, P. (2005). Nocturnal hypermotor seizures, suggesting frontal lobe epilepsy, can originate in the insula. Epilepsia, (April 2006), Vol.47, No.4, pp.755-765, ISSN 0013-9580

Sanai, N.; Polley, M.Y. \& Berger, M.S. (2009). Insular glioma resection: assessment of patient morbidity, survival, and tumor progression. Journal of neurosurgery, (January 2010), Vol.112, No.1, pp.1-9, ISSN 0022-3085

Signorelli, F.; Guyotat, J.; Schneider, F.; Isnard, J. \& Bret PH. (2010). Technical refinements for validating functional MRI-based neuronavigation data by electrical stimulation during cortical language mapping. Minimally Invasive Neurosurgery, Vol.46, No. , (October 2003), pp.265-268, ISSN 0946-7211

Signorelli, F.; Guyotat, J; Elisevich, K. \& Barbagallo, GM. (2009). Review of current microsurgical management of insular gliomas. Acta Neurochirurgica, Vol.152, No.1, (January 2010), pp.19-26, ISSN 0942-0940

Sobottka, SB.; Bredow, J.; Beutgien-Baumann, B.; Reiss, G.; Schackert, G. \& Steinmeier, R. Comparison of functional brain PET images and intraoperative brain mapping data using image-guided surgery. (2001). Computer Aided Surgery, Vol.7, No.6, (April 2002), pp. 317-325, ISSN 1092-9088

Tanriover, N.; Rhoton, A.L. Jr.; Kawashima, M.; Ulm, AJ. \& Yasuda, A. (2004). Microsurgical anatomy of the insula and the sylvian fissure. Journal of Neurosurgery, Vol.100, No.5, (May 2004), pp.891-922, ISSN 0022-3085

Türe, U.; Yaşargil, MG; Al-Mefty, O. \& Yasargil, DCH. (n.d.) Arteries of the insula. Journal of Neurosurgery, (April 2000), Vol.92, No.4, pp.676-687, ISSN 0022-3085

Yasargil, MG.; von Ammon, K.; Cavazos, E.; Doczi, T.; Reeves, JD. \& Roth, P. (1992). Tumors of the limbic and paralimbic systems. Acta Neurochirurgica, Vol.116, No.2-4, (March 1992), pp.147-149, ISSN 0001-6268

Zentner, J.; Meyer, B.; Stangl, A. \& Schramm, J. (1996). Intrinsic tumors of the insula: a prospective surgical study of 30 patients. Journal of Neurosurgery, Vol.85, No.2, (August 1996), pp.263-271, ISSN 0022-3085 


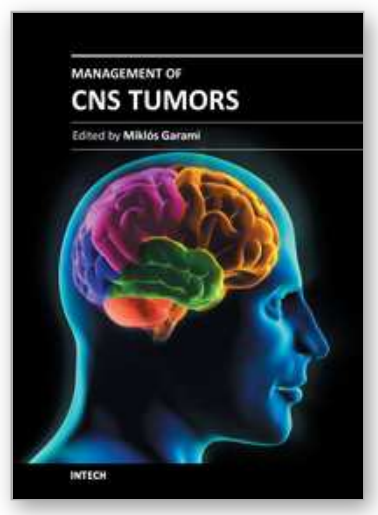

\author{
Management of CNS Tumors \\ Edited by Dr. Miklos Garami
}

ISBN 978-953-307-646-1

Hard cover, 464 pages

Publisher InTech

Published online 22, September, 2011

Published in print edition September, 2011

Management of CNS Tumors is a selected review of Central Nervous System (CNS) tumors with particular emphasis on pathological classification and complex treatment algorithms for each common tumor type. Additional detailed information is provided on selected CNS tumor associated disorders.

\title{
How to reference
}

In order to correctly reference this scholarly work, feel free to copy and paste the following:

Francesco Signorelli, Giuseppe Barbagallo, Rodolfo Maduri, Claudio Schonauer, Jacques Guyotat and Kost Elisevich (2011). Insular Tumours, Management of CNS Tumors, Dr. Miklos Garami (Ed.), ISBN: 978-953-307646-1, InTech, Available from: http://www.intechopen.com/books/management-of-cns-tumors/insular-tumours

\section{INTECH}

open science | open minds

\section{InTech Europe}

University Campus STeP Ri

Slavka Krautzeka 83/A

51000 Rijeka, Croatia

Phone: +385 (51) 770447

Fax: +385 (51) 686166

www.intechopen.com

\section{InTech China}

Unit 405, Office Block, Hotel Equatorial Shanghai

No.65, Yan An Road (West), Shanghai, 200040, China

中国上海市延安西路65号上海国际贵都大饭店办公楼405单元

Phone: +86-21-62489820

Fax: $+86-21-62489821$ 
(C) 2011 The Author(s). Licensee IntechOpen. This chapter is distributed under the terms of the Creative Commons Attribution-NonCommercialShareAlike-3.0 License, which permits use, distribution and reproduction for non-commercial purposes, provided the original is properly cited and derivative works building on this content are distributed under the same license. 